\title{
In vivo assessment of clinical, radiographic and laser fluorescence examinations for the detection of secondary caries in Class I restorations
}

\author{
Kliniczna ocena skuteczności badania klinicznego, radiologicznego i fluorescencji laserowej \\ w wykrywaniu próchnicy wtórnej w ubytkach I klasy wedtug Blacka
}

\author{
Agnieszka Witek ${ }^{\bowtie}$, Jadwiga Buczkowska-Radlińska, Maja Bendyk-Szeffer, Alicja Nowicka, Katarzyna Barczak
}

Pomorski Uniwersytet Medyczny w Szczecinie, Katedra i Zakład Stomatologii Zachowawczej i Endodoncji, al. Powstańców Wlkp. 72, 70-111 Szczecin Pomeranian Medical University in Szczecin, Department of Conservative Dentistry and Endodontics

$\triangle$ agnieszka.witek@onet.eu

\begin{abstract}
Introduction: Contemporary conservative dentistry is mainly based on work using composite materials. This is connected not only with the possibility of their comprehensive applications, but also the aesthetic effects that can be achieved through a wide variety of materials. In cases where it is not possible to make a composite restoration properly, replacing it with an alternative material which will determine the more stable reconstruction of the tooth tissues should be considered. Improper composite restoration in a relatively short period of time can lead to marginal leakage, which contributes to the accumulation of dental plaque and the development of secondary caries.

The aim of the study was to assess the effectiveness of clinical, radiographic, and laser fluorescence examinations for the detection of secondary caries under Class I amalgam fillings and composite restorations.
\end{abstract}

Materials and methods: The study involved 94 patients, aged 17-67 years. We examined 200 restorations with marginal ditching, staining, or discoloration of the adjacent tooth tissues. Teeth with visible secondary caries were not included. Clinical, laser fluorescence and radiographic examinations were performed. Results: Secondary caries was found in 137 of the 200 examined teeth. The laser fluorescence and radiographic examination methods showed low sensitivity for detecting secondary caries ( 0.31 and 0.39 respectively). Both methods showed higher specificity ( 0.86 and 0.98 respectively) and accuracy ( 0.49 and 0.58 respectively).

Conclusions: Clinical examination is the most effective method of diagnosing secondary caries in Class I restorations. Laser fluorescence and radiographic examinations should only be performed in addition to clinical examination.

Keywords: DIAGNOdent; diagnosis; radiography; secondary caries.

\begin{abstract}
ABSTRAKT
Wstęp: Współczesna stomatologia zachowawcza oparta jest głównie na pracy z materiałami kompozy towymi. Jest to związane nie tylko z możliwością ich kompleksowego zastosowania, ale także z estetycznymi względami, które można osiągnąć dzięki szerokiej gamie tych materiałów. W przypadkach, w których nie jest możliwe prawidłowe wykonanie uzupełnień kompozytowych, należy rozważyć zastąpienie go alternatywnym materiałem, który zapewni bardziej stabilną rekonstrukcję tkanek zęba. Nieprawidłowo wykonane odbudowy kompozytowe w stosunkowo krótkim czasie mogą prowadzić do powstania nieszczelności brzeżnej, co przyczynia się do akumulacji płytki nazębnej i rozwoju próchnicy wtórnej.

Celem pracy było dokonanie in vivo oceny przydatności trzech różnych metod diagnostycznych (badania klinicznego, fluorescencji laserowej oraz radiografii) w wykrywaniu próchnicy wtórnej w zębach posiadających wypełnienia amalgamatowe lub kompozytowe w klasie I wg Blacka.

Materiały i metody: Badaniem objęto grupę 94 pacjentów w wieku 17-67 lat. Oceniono łącznie 200 wypełnień z materiałów
\end{abstract}

złożonych i amalgamatu, w których stwierdzono obecność nieszczelności brzeżnej, przebarwienie brzegów wypełnienia lub przylegających tkanek zęba. Nie uwzględniano zębów z widocznymi ogniskami próchnicy wtórnej. Przeprowadzono badanie kliniczne, ocenę fluorescencji laserowej oraz badanie radiologiczne zębów zakwalifikowanych do oceny.

Wyniki: Obecność próchnicy wtórnej stwierdzono w przypadku 137 spośród 200 badanych zębów. Metoda fluorescencji laserowej i badanie radiologiczne wykazały niską czułość wykrywania próchnicy wtórnej (odpowiednio 0,31 i 0,39). Obydwie metody wykazywały natomiast wyższą swoistość (odpowiednio 0,86 i 0,98) oraz dokładność (odpowiednio 0,49 i 0,58).

Wnioski: Badanie kliniczne jest najskuteczniejszą metodą diagnozowania wtórnych ognisk próchnicy w uzupełnieniach klasy I wg Blacka. Fluorescencja laserowa oraz badania radiologiczne powinny być przeprowadzane wyłącznie w ramach uzupełnienia badania klinicznego.

Słowa kluczowe: DIAGNOdent; diagnostyka; radiowizjografia; próchnica wtórna. 


\section{INTRODUCTION}

Contemporary conservative dentistry is mainly based on work using composite materials. This is connected not only with the possibility of their comprehensive application, but also the aesthetic effects that can be achieved through a wide variety of materials. In addition, composite materials, by combining with tooth tissues by adhesion, enable minimal cavity preparation. Besides the many advantages of composite materials, they also have disadvantages that may affect the time of their functioning in the mouth. The main disadvantages of these materials include shrinkage and moisture sensitivity (during filling the cavity). In order to reduce the effect of shrinkage, the layering technique, the selection of appropriate bonding systems, and the use of a curing lamp with a soft-start function are recommended. The size of the shrinkage also depends on the factor $\mathrm{C}$ configuration, which is particularly disadvantageous in Black's Class I. The forces occurring during the polymerization of the material are more negative and cause a greater distribution of stress inside the material in geometrically shaped cavities $[1,2]$. Salivary or blood contamination of the cavity prior to or while placing the composite material significantly reduces the adhesion forces and increases microleakage. Both facts reduce the marginal integrity of composite restorations and shorten the time of their unharmed persistence in the oral cavity.

In cases where it is not possible to make a composite restoration properly, replacing it with an alternative material which will determine the more stable reconstruction of the tooth tissues should be considered. Improper composite restoration in a relatively short period of time can lead to marginal leakage, which contributes to the accumulation of dental plaque and the development of secondary caries [3].

Secondary caries is a major reason for replacing restorations. However, it is difficult to detect in the early stages $[4,5]$. Stained composite margins and ditched amalgam margins are not necessarily signs of decay, although they indicate a greater risk $[4,5]$. Visual examination with a tactile instrument is still one of the most common techniques for the detection of secondary caries. Several additional diagnostic methods are currently available, such as electrical conductance measurement, light- and laser-induced fluorescence, fiberoptic transillumination, radiographic examination, and CBCT [5].

The aim of this in vivo study was to evaluate the performance of three different methods: visual examination, laser fluorescence (DIAGNOdent pen 2190, Kavo, Biberach, Germany), and radiography for secondary caries detection in Class I composite and amalgam restorations.

\section{MATERIALS AND METHODS}

The present study population involved 94 patients. Within this population we examined 200 Class I restorations (101 amalgams and 99 resin-based composites) with marginal ditching, staining, or discolorations of the adjacent tooth tissues. Teeth with visible secondary caries were excluded. The study protocol was approved by the Pomeranian Medical University in Szczecin (Poland) Ethics Committee (number KB-0012/50/10).

Standardized diagnostic procedures were applied following the current International Caries Detection and Assessment System (ICDAS II, CARS detection criteria) guidelines, using a standard diagnostic kit comprising a dental mirror, a probe, and cotton pliers. Caries Associated with Restorations and Sealants (CARS) describes caries adjacent to the restorations or sealants. Caries associated with restoration and sealant codes: Code 0 . Sound tooth surface with restoration or sealant.

Code 1. First visual change in enamel.

Code 2. Distinct visual change in enamel/dentin adjacent to a restoration/sealant margin.

Code 3. Carious defects of $<0.5 \mathrm{~mm}$, with signs of code 2 .

Code 4. Marginal caries in enamel/dentin/cementum adjacent to restoration/sealant, with underlying dark shadow from dentin.

Code 5. Distinct cavity adjacent to restoration/sealant. Code 6. Extensive distinct cavity with visible dentin [6].

Prior to visual examination and laser fluorescence measurement, the restoration margins of each tooth were carefully cleaned and dried. Visual examination included assessment for the presence or marginal ditching, staining, or tooth discoloration adjacent to the restoration (CARS, code 1-4).

As a complement to the clinical examination, laser fluorescence measurements were performed with a DIAGNOdent pen 2190. Before each measurement, the DIAGNOdent pen was calibrated against the supplied ceramic standard, and zeroed on the sound enamel of each test tooth. The cone-shaped FISSURE probe was used to access the tooth tissues adjacent to the restoration, and the margin between the restoration and the tooth tissue was carefully scanned with the DIAGNOdent pen. The highest reading was recorded and was interpreted in accordance with the Hibst and Paulus scale. A measurement of greater than 30 was considered to indicate the presence of secondary caries.

For radiographic examination, bitewings were taken with the paralleling technique (Digora Optime Eco, Soredex, Tuusula, Finland) using film-holding devices. All radiographs were examined for secondary caries detection on the same computer screen by two dentists. They independently evaluated the images for the decision of the presence or absence of secondary caries.

After completing all examinations, the restorative material was removed from the cavity using a bur in a high-speed hand-piece under copious water coolant. Great care was taken to avoid bur contact with the cavity walls and the restorative margins. The small remnants of restorative material in the cavity undercuts were removed using a sharp excavator. All cavities were cleaned and dried, and the enamel-dentine junction was examined using a sharp dental probe for its consistency (hard/soft). The results were recorded. All studies were performed by two examiners independently.

\section{Statistical analysis}

Statistical analyses were performed using the statistical program STATA 11, License No. 30110532736. All continuous variables were checked for normality of distribution using the 
Kolmogorov-Smirnov test. Statistical differences between two groups were examined using Student's t-test or the MannWhitney test. Multiple group comparisons were performed using analysis of variance (ANOVA) or the Kruskal-Wallis test. Discrete variables are described by the amount and frequency. Pearson's $\chi^{2}$ test or Fisher's exact test were used to test the statistical dependencies between discontinuous variables. Spearman's rank correlation was used to study the correlation between discrete variables, including ordinal and nominal (variables coded 0/1) and continuous variables. The results are described by the coefficient of correlation $r$ and the probability $\mathrm{p}$. The level of significance for all tests was $\mathrm{p}<0.05$.

The laser fluorescence and radiographic examination methods were assessed based on sensitivity, specificity, and accuracy. Sensitivity, specificity and accuracy of laser fluorescence and radiography were calculated at all threshold values. The effectiveness of clinical examination in the diagnosis of secondary caries in Class I restoration was assessed by positive predictive value.

\section{RESULTS}

The results of measurements with the DIAGNOdent pen and radiographic examination, and performed prior to filling removal, as well as the results of clinical examination carried out after removal of the fillings are presented in Table 1. The clinical examination revealed secondary caries in 137 teeth, of which 69 had composite restoration and 68 amalgam restoration. Differences between these groups were not statistically significant. Laser fluorescence measurement showed secondary caries in 52 teeth: 28 with amalgam restoration and 24 with composite restoration. The difference between these groups was not statistically significant. Analysis of bitewing radiographs revealed the presence of secondary caries in 54 teeth, of which 15 had amalgam restorations and 39 composite restorations. This difference was highly statistically significant (Table 1).

The agreement between all diagnostic methods for detecting secondary caries lesions are presented in Table 2. Among the examined teeth with amalgam restoration, $34 \%$ received the same diagnosis of secondary caries from both the clinical examinations and DIAGNOdent pen readings, while $15 \%$ of tooth measurements showed a presence of caries that was not confirmed by clinical examination. The results obtained significantly differed between these two diagnostic methods.
TABLE 2. Inter-examiner agreement for laser fluorescence, radiographic and clinical examination methods for detecting secondary caries lesion in teeth with amalgam and composite restorations

\begin{tabular}{lcccc}
\multicolumn{5}{c}{ Clinical examination } \\
\hline \multirow{2}{*}{ Method } & $\begin{array}{c}\text { restorative } \\
\text { material }\end{array}$ & yes & no & p \\
\hline \multirow{2}{*}{$\begin{array}{l}\text { Laser } \\
\text { fluorescence }\end{array}$} & amalgam & $23(34 \%)$ & $5(15 \%)$ & 0.04928 \\
\cline { 2 - 5 } & composite & $20(29 \%)$ & $4(13 \%)$ & 0.09490 \\
\hline \multirow{2}{*}{ Radiography } & amalgam & $15(22 \%)$ & $0(0 \%)$ & 0.00346 \\
\cline { 2 - 5 } & composite & $38(55 \%)$ & $1(3 \%)$ & 0.00001 \\
\hline
\end{tabular}

TABLE 3. Sensitivity, specificity, and accuracy of laser fluorescence and radiographic examination methods for detecting secondary caries

\begin{tabular}{lcccc}
\multicolumn{1}{c}{ Method } & Sensitivity & Specificity & Accuracy & p \\
\hline $\begin{array}{l}\text { Laser } \\
\text { fluorescence }\end{array}$ & 0.31 & 0.86 & 0.49 & 0.01043 \\
\hline Radiography & 0.39 & 0.98 & 0.58 & 0.00001 \\
\hline
\end{tabular}

TABLE 4. Sensitivity, specificity, and accuracy of laser fluorescence and radiographic examination methods for detecting secondary caries in teeth with amalgam or composite restorations

\begin{tabular}{lccccc}
\multirow{2}{*}{ Method } & $\begin{array}{c}\text { Restorative } \\
\text { material }\end{array}$ & Sensitivity & Specificity & Accuracy & p \\
\hline \multirow{2}{*}{$\begin{array}{l}\text { Laser } \\
\text { fluorescence }\end{array}$} & amalgam & 0.34 & 0.85 & 0.51 & 0.04928 \\
\cline { 2 - 6 } & composite & 0.29 & 0.87 & 0.47 & 0.09490 \\
\hline \multirow{2}{*}{ Radiography } & amalgam & 0.22 & 1.00 & 0.48 & 0.00346 \\
\cline { 2 - 6 } & composite & 0.55 & 0.97 & 0.68 & 0.00001 \\
\hline
\end{tabular}

Among the teeth with composite restoration, 29\% received the same diagnosis of secondary caries from both the clinical examination and the DIAGNOdent pen readings, while $13 \%$ ( 4 teeth) were diagnosed by DIAGNOdent pen examination with secondary caries that were not confirmed by clinical examination. The difference between the results of these methods was at the borderline of statistical significance. The results of clinical examinations and radiography for the diagnosis of secondary caries were the same in $22 \%$ of teeth with amalgam restorations, and in $55 \%$ of teeth with composite restorations. The differences between methods were statistically significant.

The sensitivity, specificity, and accuracy of laser fluorescence and radiographic examination methods used to diagnose secondary caries in Class I reconstructions are presented in Tables 3 and 4. The effectiveness of clinical examination for the detection of secondary caries in Class I reconstructions was determined based on the positive predictive value, which was 0.69 .

TABLE 1. The results of clinical, laser fluorescence and radiographic examination methods for detecting secondary caries in teeth with amalgam or composite restoration

\begin{tabular}{|c|c|c|c|c|c|c|c|c|c|}
\hline \multirow{2}{*}{$\begin{array}{c}\text { Restorative } \\
\text { material }\end{array}$} & \multicolumn{3}{|c|}{ Clinical examination } & \multicolumn{3}{|c|}{ Laser fluorescence } & \multicolumn{3}{|c|}{ Radiography } \\
\hline & yes & no & $p$ & yes & no & $p$ & yes & no & $p$ \\
\hline Amalgam & $\begin{array}{c}68 \\
(67 \%)\end{array}$ & $\begin{array}{c}33 \\
(33 \%)\end{array}$ & 0.718 & $\begin{array}{c}28 \\
(28 \%)\end{array}$ & $\begin{array}{c}73 \\
(72 \%)\end{array}$ & 0.575 & $\begin{array}{c}15 \\
(15 \%)\end{array}$ & $\begin{array}{c}86 \\
(85 \%)\end{array}$ & 0.0001 \\
\hline Composite & $\begin{array}{c}69 \\
(70 \%)\end{array}$ & $\begin{array}{c}30 \\
(30 \%)\end{array}$ & & $\begin{array}{c}24 \\
(24 \%) \\
\end{array}$ & $\begin{array}{c}75 \\
(76 \%) \\
\end{array}$ & & $\begin{array}{c}39 \\
(39 \%) \\
\end{array}$ & $\begin{array}{c}60 \\
(61 \%) \\
\end{array}$ & \\
\hline
\end{tabular}




\section{DISCUSSION}

The diagnosis of secondary caries is often based on clinical examination findings of symptoms, such as microleakage, marginal staining, or discoloration of tooth tissues adjacent to the restoration. However, many studies have indicated that these symptoms are not directly related to the development of secondary caries. The presence of microleakage can lead to the accumulation of bacterial plaque, especially in patients with inadequate oral hygiene and a predisposition to secondary caries development $[1,4,7,8,9,10,11,12]$.

In our study we examined 200 fillings with visible defects within the margins of the restoration. Clinical examination conducted after the removal of the restorations revealed the presence of secondary caries in 137 teeth, of which 68 had dental amalgam fillings (representing $67 \%$ of the total examined teeth with dental amalgam fillings) and 69 had composite restorations (representing 70\% of the examined teeth with composite restorations). This difference between restoration types was not statistically significant. In contrast to our present findings, Krupiński et al. evaluated amalgam and composite Class I restorations with marginal defects, and found the presence of secondary caries in up to $27 \%$ of amalgam restorations and $72 \%$ of composite restorations [13]. A study conducted by Bernardo et al. obtained similar results [14]. Among defective amalgam and composite restorations, secondary caries was found in only $22.1 \%$ of amalgam restorations and $77.9 \%$ of teeth with composite filling.

The effectiveness of clinical examination for the diagnosis of secondary caries in Class I restorations was reflected by a positive predictive value of 0.69 . This finding confirms that the presence of marginal defects in restorative materials does not necessarily indicate the presence of secondary caries. To avoid unnecessary filling replacements, many authors recommend the use of additional diagnostic methods as a complement to clinical examination $[14,15]$.

Bitewing radiographs are thought to be important for the diagnosis of secondary caries within posterior teeth. However, many factors may influence secondary caries detection, such as the proximity of the lesion to adjacent restorations, lesion size and three-dimensional orientation, projection of the image, and optical factors derived from differences in the radiopacity of the restorative materials, lesion, and dental structures $[16,17,18,19]$. Several studies have indicated that the restorative materials are more radiopaque than the dentin, and more or equally radiopaque compared to enamel. This increased radiopacity of restorative materials reduces caries detection. Materials with greater radiopacity than dental structures, such as amalgam, can hide or mask secondary caries, making diagnosis difficult $[17,18,19]$. Numerous authors recommend additional diagnostic methods for the detection of secondary caries, besides clinical and radiographic examinations, such as laser fluorescence, to avoid unnecessary filling replacement $[14,15,16,20,21]$.

In our study, radiographic examination revealed the presence of secondary caries in $15 \%$ of teeth filled with amalgam and $39 \%$ teeth with composite restorations. These proportions were significantly lower compared to the results obtained from clinical examination performed after restoration removal, for both types of restorations. The agreement of secondary caries diagnosis between both examination methods was $22 \%$ among teeth with amalgam restorations, and $55 \%$ in teeth with composite restorations. A similar study performed by Hewlett et al. showed agreement of secondary caries diagnosis between clinical and radiographic examination methods in only $12 \%$ of teeth with amalgam restorations and $25 \%$ of teeth restored with composite [22]. Those authors suggest that clinical examination combined with radiographic interpretation increases the effectiveness of secondary caries diagnosis.

In this study the DIAGNOdent pen 2190 was used, which is a new version of the popular DIAGNOdent. The usefulness of this device in the assessment of secondary caries in Class I restorations has been examined in only a few studies. The DIAGNOdent pen measurements and the clinical findings were in agreement in indicating secondary caries in $34 \%$ of amalgam fillings and $29 \%$ of composite fillings. Laser fluorescence examination misdiagnosed recurrent caries in five amalgam fillings and four composite ones, with no correlation between the type of material and the DIAGNOdent pen results. The literature includes reports of a possible impact of the applied material on the DIAGNOdent reading. Pretty et al. showed that restorations made of amalgam or GIC can depress the value of the DIAGNOdent reading, while composites and compomers may increase the measurement results obtained with this reflectometric device. However, the same authors did not demonstrate such dependence in in vitro studies [23]. The value measured with a DIAGNOdent device may also be affected by discoloration of both the tooth tissue and the filling material [24]. Hitij and Fidler concluded that discoloration or porous surface of the filling material may decrease the rate of secondary caries detection with DIAGNOdent. They further reported that polishing of the composite surface before DIAGNOdent examination effectively reduces the potential risk of diagnostic error [25]. A similar study by Bamzahim et al. showed that the presence of dental plaque can cause a false positive diagnosis of secondary caries. Therefore, these researchers concluded that DIAGNOdent can provide a valuable complement to radiographic examination [26]. Hall et al. [27] and Ando et al. [5] also rated the usefulness of laser fluorescence for the diagnosis of secondary caries around amalgam fillings in Class I. The results obtained in their studies suggest that laser fluorescence may improve the ability to detect early secondary caries around amalgam restorations and be useful in detecting early caries stages within the enamel, and for monitoring its possible progression. Another result was obtained by Diniz et al. [15]. The authors concluded that clinical examination using visual criteria (ICDAS) and laser fluorescence measurement were useful in detecting secondary caries only around resin composite restorations, whereas around amalgam restorations all methods seemed to be questionable. Diniz et al. in other studies showed that the ICDAS and bitewing radiograph methods 
presented the best performance in detecting caries lesions affecting enamel and dentin in teeth with amalgam restorations [28].

Assessment of sensitivity, specificity, and accuracy of both diagnostic methods for detecting secondary caries revealed that laser fluorescence had a sensitivity of 0.34 and a specificity of 0.87 in teeth with amalgam fillings, and a sensitivity of 0.29 and a specificity of 0.87 in teeth with composite. Boston performed in vitro tests of secondary caries detection around amalgam fillings using the DIAGNOdent pen [29]. The author obtained different results in his study and reported a sensitivity of up to 0.67 and specificity of up to 0.79 . The author suggests that DIAGNOdent can effectively increase the accuracy of clinical diagnoses of secondary caries. In our study radiographic examination had a very low sensitivity of 0.22 in amalgam fillings, and a higher sensitivity of 0.55 in composite fillings. The radiographic study specificity was 1.00 in amalgam fillings and 0.97 in composite fillings. These findings led us to conclude that this test should not be used alone for secondary caries diagnosis, particularly in cases of suspicion of recurrent caries next to Black's classification Class I amalgam filling. Bamzahim et al. previously evaluated 51 teeth with amalgam fillings in Class I for the presence of secondary caries, and reported that radiographic examination showed a sensitivity of 0.81 and specificity of 0.92 [26].

The substantial discrepancy between our present results and those reported previously suggests an overwhelming need for further analysis/investigation of the effectiveness of these diagnostic methods in detecting secondary caries. However, all the authors who have investigated this subject, regardless of the results, agree on two facts: that the diagnostic process should be optimized to minimize the risk of a false-positive caries diagnosis, and invasive treatment must be reduced in all unjustified cases.

\section{CONCLUSIONS}

Clinical examination is the most effective way to diagnose secondary caries in Class I restorations. Laser fluorescence and radiographic examinations should only be used in addition to clinical examination.

\section{REFERENCES}

1. Braga RR, Boaro LCC, Kuroe T, Azevedo CLN, Singer JM. Influence of cavity dimensions and their derivatives (volume and ' $\mathrm{C}$ ' factor) on shrinkage stress development and microleakage of composite restorations. Dent Mater 2006;22:818-23.

2. Giachetti L, Russo DS, Bambi C, Grandini R. A review of polymerization shrinkage stress: current techniques for posterior direct resin restorations. J Contemp Dent Pract 2006;7:1-14.

3. Cenci MS, Pereira-Cenci T, Cury JA, Ten Cate JM. Relationship between gap size and dentine secondary caries formation assessed in a microcosm biofilm model. Caries Res 2009;43:97-102.

4. Kidd EAM, Joyston-Bechal S, Beighton D. Marginal ditching and staining as a predictor of secondary caries around amalgam restorations: a clinical and microbiological study. J Dent Res 1995;74:1206-11.
5. Ando M, González-Cabezas C, Isaacs RL, Eckert GJ, Stookey GK. Evaluation of several techniques for the detection of secondary caries adjacent to amalgam restorations. Caries Res 2004;38:350-6.

6. Shivakumar KM, Prasad S, Handu GN; International Caries Detection and Assessment System. A new paradigm in detection of dental caries. J Conserv Dent 2009;12:10-6.

7. Totiam P, González-Cabezas C, Fontana MR, Zero DT. A new in vitro model to study the relationship of gap size and secondary caries. Caries Res 2007;41:467-73.

8. Fabianelli A, Pollington S, Davidson CL, Cagidiaco MC, Goracci C. The relevance of micro-leakage studies. Int Dent South Afr 2007;9:64-74.

9. Lima FG, Romano AR, Correa MB, Demarco FF. Influence of microleakage, surface roughness and biofilm control on secondary caries formation around composite resin restorations: an in situ evaluation. J Appl Oral Sci 2009;17(1):61-5. doi: 10.1590/S1678-77572009000100012.

10. Sousa RP, Zanin IC, Lima JP, Vasconcelos SM, Melo MA, Beltrão HC, et al. In situ effects of restorative materials on dental biofilm and enamel demineralisation. J Dent 2009;37:44-51.

11. Gupta KV, Verma P, Trivedi A. Evaluation of microleakage of various restorative materials: an in vitro study. J Life Sci 2011;3:29-33.

12. Nedeljkovic I, Teughels W, De Munck J, Van Meerbeek B, Van Landuyt KL. Is secondary caries with composites a material-based problem? Dent Mater 2015;31(11):e247-77. doi: 10.1016/j.dental.2015.09.001.

13. Krupiński J, Krupińska A, Lejman L, Modelska D, Roterman I, Sciegienny-Malec J, et al. Clinical pattern of secondary dental caries in relation to tissue defect class and type of filling material. Czas Stomatol 1990;43:595-9.

14. Bernardo M, Luis H, Martin MD, Leroux BG, Rue T, Leitão J, et al. Survival and reasons for failure of amalgam versus composite posterior restorations placed in a randomized clinical trial. J Am Dent Assoc 2007;138:775-8.

15. Diniz MB, Eckert GJ, González-Cabezas C, Cássia Loiola Cordeiro R, Gonçalves Ferreira-Zandona A. Caries detection around restorations using ICDAS and optical devices. J Esthet Restor Dent 2016;28:110-21.

16. Pitts NB. Clinical diagnosis of dental caries: a European perspective. J Dent Educ 2001;65:972-8.

17. Gordan VV, Riley JL, Carvalho RM, Snyder J, Sanderson JL, Anderson M, et al. Methods used by dental practice-based research network (DPBRN) dentists to diagnose dental caries. Oper Dent 2011;36:2-11.

18. Braga MM, Chiarotti APS, Imparato JCP, Mendes FM. Validity and reliability of methods for the detection of secondary caries around amalgam restorations in primary teeth. Braz Oral Res 2010;24:102-7.

19. Moreira PL, Messora MR, Pereira SM, de Almeida SSM, da Cruz AD. Diagnosis of secondary caries in esthetic restorations: influence of the incidence vertical angle of the x-ray beam. Braz Dent J 2011;22:129-33.

20. Brouwer F, Askar H, Paris S, Schwendicke F. Detecting secondary caries lesions. A systematic review and meta-analysis. J Dent Res 2016;95:143-51.

21. Pedrosa RF, Brasileiro IV, dos Anjos Pontual ML, dos Anjos Pontual A, da Silveira MM. Influence of materials radiopacity in the radiographic diagnosis of secondary caries: evaluation in film and two digital systems. Dentomaxillofac Radiol 2011;40:344-50.

22. Hewlett ER, Atchison KA, White SC, Flack V. Radiographic secondary caries prevalence in teeth with clinically defective restorations. J Dent Res 1993;72:1604-9.

23. Pretty IA, Smith PW, Edgar WM, Highama SM. Detection of in vitro demineralization adjacent to restorations using quantitative light induced fluorescence (QLF). Dent Mater 2003;19:368-74.

24. Kulczyk T, Dyszkiewicz-Konwińska M, Owecka M, Krzyżostaniak J, Surdacka $A$. The influence of amalgam fillings on the detection of approximal caries by cone beam CT: in vitro study. Dentomaxillofac Radiol 2014;43(7):20130342. doi: 10.1259/dmfr.20130342.

25. Hitij T, Fidler A. Effect of dental material fluorescence on DIAGNOdent readings. Acta Odontol Scand 2008;66(1):13-7.

26. Bamzahim M, Aljehani A, Shi XQ. Clinical performance of DIAGNOdent in the detection of secondary caries lesions. Acta Odontol Scand 2005;63:26-30.

27. Hall AF, Deschepper E, Stookey GK. In vitro studies of laser fluorescence for detection and quantification of mineral loss from dental caries. Adv Dent Res 1997;11:507-14.

28. Diniz MB, Cordeilo RCL, Ferreira-Zandona AG. Detection of caries around amalgam restorations on approximal surfaces. Oper Dent 2016;41:34-43.

29. Boston DW. Initial in vitro evaluation of DIAGNOdent for detecting secondary carious lesions associated with resin composite restorations. Quintessence Int 2003;34:109-16. 